\title{
Dealing with in-class challenges: Pre-service teacher cognitions and influences
}

\author{
Şeyda Selen Çimen ${ }^{a} *$ (i) , Ayşegül Daloğlu ${ }^{\text {b }}$ \\ ${ }^{a}$ Muğla Sitkı Koçman University, Muğla Üniversitesi Eğitim Fakültesi Yabancı Diller Eğitimi Bölümü, Muğla 48000, Turkey \\ ${ }^{b}$ Middle East Technical University, Orta Doğu Teknik Üniversitesi Eğitim Fakültesi Yabancı Diller Eğitimi Bölümü, Ankara 06800, Turkey
}

\section{APA Citation:}

Çimen, Ş. S., \& Daloğlu, A. (2019). Dealing with in-class challenges: Pre-service teacher cognitions and influences. Journal of Language and Linguistic Studies, 15(3), 754-772.

Submission Date:12/25/2018

Acceptance Date:22/07/2019

\begin{abstract}
This study explores cognitions of pre-service English language teachers in relation to dealing with most commonly experienced in-class challenges in foreign language teaching and the influences that shape their cognitions. Adopting qualitative research design, a case study was conducted to provide an account of pre-service English language teachers' cognitions. Data for this study were collected in two main stages. The first stage involved collection of the base-line data through an open-ended questionnaire with a view to identifying in-class challenges experienced by in-service English language teachers. The second stage included scenario-based interviews with pre-service teachers that took place before and after the practicum. Results of the study reveal that (1) pre-service teachers generated various strategies in their pre- and post-practicum cognitions; (2) there were traces of change in cognitions due to practicum; (3) courses in teacher education program, pre-service teachers' own learning experiences, and practicum experiences emerged as influences that shape their cognitions.
\end{abstract}

(C) 2019 JLLS and the Authors - Published by JLLS.

Keywords: Pre-service English language teacher; teacher cognition; influences; in-class challenges; practicum

\section{Introduction}

Teacher cognition research, "the investigation of the hidden side of teaching to illuminate teaching behaviors and classroom processes" became a focus of educational research in the late 1960s and early 1970s, whereas studies of teacher cognition in the field of second/foreign language teaching began in the early 1990s (Tsui, 2011, p. 25). With this focus of investigation into teachers' psychological processes on which they establish their classroom practices, teaching started to be viewed as thoughtful behavior, rather than only behaviors; and in parallel, teachers as active, thinking decision-makers, not mechanical implementers of external prescriptions (Borg, 2006). It is observed that the body of research in teacher cognition has also brought a "paradigm shift in teacher education from the identification of effective teaching behaviors to an understanding of the unobservable aspects of teaching from the participant's perspective rather than from the researcher's perspective" (Tsui, 2011, p. 25).

* Corresponding author. Tel.: +0-000-000-0000

E-mail address: s.selen.ozkan@gmail.com 
It is observed that there is a lack of research into teacher cognition regarding in-class challenges in foreign language teaching and dealing with them. Therefore, this study attempts to contribute existing literature by shedding light on English language teachers' perceived challenges in foreign language teaching and pre-service English language teachers' cognitions in relation to dealing with those challenges.

\subsection{Research on language teacher cognition}

Studies on language teacher thinking have been centered on a number of issues such as teachers' and pre-service teachers' (PTs') decision making processes, their cognitions on specific domains like grammar teaching and teaching reading, cognitions of novice teachers in the induction year, the influences that shape teacher cognition and practices, and the relationship between teachers' cognitions and instructional practices.

Change in teacher beliefs and the impact of in-service trainings, pedagogical treatments, teacher education programs or specific courses on teacher beliefs are another focus of cognition research, which is also addressed as a research question in this study. Existing literature on belief change presents contrasting results. There are studies concluding that beliefs are resistant to change (Pennington and Urmston, 1998; Urmston, 2003; and Borg, M., 2005) while other studies reveal that beliefs are changeable due to the impact of, for example, teacher education, reflection on action, and teaching experience (Cabaroglu and Roberts, 2000; Woods and Cakır, 2011; and Basturkmen, 2012). On the other hand, some studies produced mixed results (Han, Shin, and Ko, 2017; Polat, 2010; and Liu and Fisher, 2006) as reporting shift in beliefs varying according to degree of change, aspects of language teaching or features of participants. Moreover, what was more outstanding in Borg's (2011) and Phipps' (2007) studies is teachers' raising their awareness of existing beliefs after the in-service training rather than change in beliefs.

As for the methodology used in researching language teacher cognition and practice, Borg's (2012) analysis of the twenty-five contemporary studies revealed that the field is international in scope, uses non-probability samples, involves non-native English speaking teachers, is modest in scale, uses mixed method or qualitative methods in either cross-sectional or longitudinal design, and is multi-method in nature. He also made a critical commentary and called for the need for greater specificity in the selection of participants, and more concrete detail about how data are collected and analyzed. Clark and Peterson (1984), stating that research on thought processes depends heavily on various forms of self-report by teachers, highlighted the methodological problem of "how to elicit and interpret valid and reliable selfreports about cognitive processes" (p. 14).

Moreover, Borg's (2003) review indicated that there was a lack of sense of unity in the cognition research terminology in that "the study of teacher cognition is characterized by a multiplicity of labels (...) and a proliferation of terms [which] has led to a definitional confusion (p. 83). Breen, Hird, Milton, Oliver, and Thwaite, (2001) highlighted the wide range of terms which are "diverse, sometimes overlapping or distinctive" in teacher cognition research (p. 472). Pajares (1992) also mentioned "a variety of meanings" in defining theoretical constructs in the field. Borg (2006) warned the field researchers about the consistent use of a shared set of concepts and definitions for the continuing development of the field. Some of the terms that have been used in language teacher cognition research so far are BAK -Beliefs, Assumptions, and Knowledge- (Woods, 1996), PPK -personal practical knowledge- (Clandinin, 1985; Golombek, 1998; 2009), practical knowledge (Meijer, Verloop, and Beijard, 1999; Gholami and Husu, 2010), epistemological beliefs (Flores, 2001), theories for practice (Burns, 1996), KAL -Knowledge About Language (Bartels, 2009; and Borg, 2005), folklinguistic theories (Warford and Reeves, 2003), and teachers' maxims in language teaching (Richards, 1996). 


\subsection{Influences that shape language teacher cognition}

The influence of different entities in teachers' lives on their thought processes and instructional practices has been the subject of educational research since research into teacher cognition gained popularity. Borg (2003) reflects findings from the studies he reviewed and concludes that "a wide range of interacting and often conflicting factors shape language teachers' cognitions and instructional practices" (p. 91). Farrel (2008) regards learning teaching as a complex process and lists some influences that have impact on first year teachers. He accepts the influence of previous schooling and teacher education program; and emphasizes the influence of first year socialization into an established school culture. In parallel, Urmston's (2003) longitudinal study's results revealed that pre-service English language teachers' own experiences as students and the time they spend in classrooms for practice teaching strongly influence their beliefs and knowledge about teaching English. There are studies that found out the influence of teachers' own language learning experiences on their instructional practices, i.e. the "apprenticeship of observation" (term by Lortie, 1975). Starting from the point of view that "we teach as we have been taught", Bailey, Bergthold, Braunstein, Fleichman, Holbrook, Tuman, Waissbluth, and Zambo (1996, p. 11) examined the apprenticeship of observation with seven teacherlearners and one teacher educator through autobiography assignments and journal entries. They found traces of apprenticeship of observation in four aspects of teaching: teaching behaviors and beliefs, maintaining motivation, and affect and atmosphere. Numrich (1996) is another researcher who examined twenty-six novice teachers' diary entries and proposed that "the effect of learning an L2 is often carried over to the teaching of an L2" either by replicating or rejecting techniques used by previous teachers (p. 137).

The influence of teacher education programs on teachers' cognition and practices and the extent of this influence have also been investigated but the results are controversial. There are studies claiming that teacher education has a limited or weak impact on teachers' cognitions and practices. Richards and Pennington's (1998) study revealed interesting results regarding the reflection of teacher education program on teachers' teaching practices. Results of the study in which they studied five M.A. students in their first year of teaching in Hong Kong suggested that the teachers mostly ignored and abandoned the principles they had been taught in their teacher preparation program. In another study carried out again in Hong Kong, Pennington and Urmston (1998) concluded that "graduating English language teachers were not greatly affected by the coursework in the teacher preparation program" (p. 34), and they highlighted "the need for teacher education course planners to become more attuned where not only the language but also the culture of teaching is foreign" (p. 35). Similarly, Urmston (2003) expressed that 'they [teachers' beliefs and knowledge about teaching] are changed relatively less by the training that they receive in their BA courses" (p. 112).

In contrast, there are studies that reported strong influence of teacher education programs and courses on pre-service teachers' cognitions and practices. Gomez (1990) concluded that features of the teacher education program, together with a set of interrelated features of the school context, alter or challenge teachers' beliefs. Grisham (2000) looked at the influence of the teacher education program on preservice teachers' cognitions regarding reading instruction and concluded that the program has an impact on the pre-service teachers since they get more constructivist throughout the program. Richards, Ho, and Giblin (1996) traced changes in five trainee teachers' cognitive and behavioral activity in terms of their conceptions of their role as teachers, developing professional talk about teaching, problematic dimensions of teaching, and perspectives on successful lessons. Tüzel and Akcan's (2009) study, which investigated pre-service English language teachers' challenges in using the target language in their classroom practices during practicum, revealed that "the language awareness training had a positive impact on the target language use" (p. 271). 
Finally, comparing the influence of teacher education program and teachers' previous learning experiences on classroom practices, Williams and Burden (1997) claimed that previous experiences and deep-rooted beliefs about language learning might be more influential than a particular methodology learnt in a teacher education program.

\subsection{Research questions}

This study aims to address the following research questions:

1. What are pre-service English language teachers' cognitions in relation to dealing with most commonly experienced in-class challenges in foreign language teaching prior to and after practicum?

2. Is there any change in pre-service English language teachers' cognitions in relation to dealing with most commonly experienced in-class challenges prior to and after practicum?

3. What are the influences that shape pre-service English language teachers' cognitions in relation to dealing with most commonly experienced in-class challenges?

\section{Method}

This study adopts qualitative research design due to the suitability of the research topic to this design, characteristics of qualitative research, and the convenience of those characteristics in addressing the research questions. Therefore, a case study was conducted to provide an account of pre-service English language teachers' cognitions in relation to dealing with most commonly experienced in-class challenges and the influences on them.

\subsection{Participants and sampling}

In-service EFL (English as a foreign language) teachers working at public secondary schools in a city in Turkey and pre-service EFL teachers enrolled in a four-year language teacher education program at a state university make up the participants of this case study.

Two types of sampling strategies were used in this study. In-service EFL teachers were reached through snowball sampling. To reach "a principled list of key respondents" (Dörnyei, 2007, p. 129), school visits were made to collect data from in-service EFL teachers and then e-mailing was used to recruit further respondents with the help of teachers met at the school visits.

This study also employed purposive sampling for the group of pre-service EFL teachers. That is, to reach a complete understanding of the process investigated in this study, the researcher consulted with the faculty of the department of foreign languages teaching to study with a group of pre-service EFL teachers. The researcher was permitted to conduct interviews in a group of six pre-service teachers who were going to start their school-based practicum at a public secondary school and volunteered to participate in the study.

\subsubsection{In-service English language teachers}

Respondents who provided the base-line data for the study were twenty EFL teachers working at seven different public secondary schools in the same city. They were asked to give written responses to 'Questionnaire to Determine the In-class Challenges.' They took part in the study on a voluntary basis. Nine of the teachers were females and eleven were males; their year of experience ranged between 0-5 years and 20 and more years; fifteen teachers were graduates of ELT departments and five had graduated from departments of English philology and English linguistics. Therefore, there was variety in gender, 
years of experience and educational background among participants. That is, it can be said that we could hear the voices of EFL teachers of different characteristics as informants for the base-line data.

\subsubsection{Pre-service English language teachers}

Main participants of this study were specified as pre-service EFL teachers enrolled in a four year language teacher education program at a state university in Turkey. Borg (2006, p. 50) defines preservice teachers as "those engaged in initial teacher education programmes (...) who typically have no formal language teaching experience." Parallel to this definition, pre-service EFL teachers in this study consisted of six senior students who have not had any formal teaching experience before. All six of them as a group attended the same secondary school in the city center. They were the mentees of one mentor teacher at the school and were supervised by the same instructor at the Department. The average of their ages was 21.5 and their GPAs ranged from 2.90 to 3.51. Five of the six pre-service teachers were females, and one was male. The researcher did not intervene in the formation of this group. The group was assigned to the university instructor randomly by the student affairs system.

\subsection{Instruments}

\subsubsection{Questionnaire for determining in-class challenges}

A questionnaire for determining in-class challenges was designed to obtain real challenges as experienced by teachers. The term 'in-class challenges' is operationalized in this study as challenges occurring during the course of class or while getting prepared for the class. The questionnaire included no pre-existing categories in order not to limit teachers. Teachers were free to describe in detail three in-class challenges they mostly experience while teaching EFL. By this way, approximately sixty descriptions of in-class challenges were obtained for later use in developing scenarios of in-class challenges.

\subsubsection{Scenario-based interviews}

For this study, scenarios can be operationalized as "brief descriptions of typical instructional situations" and scenario-based interviews as "semi-structured interviews that participants are invited to respond to orally through a series of prompts" (Borg, 2006, p. 192). The base-line data served as a basis to create case scenarios for the collection of cognition data. After the descriptions of in-class challenges were analyzed and classified, frequencies were calculated. The in-class challenges with four and more frequency were transformed into case scenarios, which made nine case scenarios in total. The case scenarios were the contextualized versions of teachers' descriptions of challenges they experience. Therefore, the scenarios included concrete contextual detail of the events, such as fictitious names of teachers and students, grade levels, topics that are taught together with the teaching techniques and activity types. Standards for scenario writing suggested by Santoro and Allard (2008) were taken into consideration while creating the scenarios.

Two sets of nine case scenarios were created: one set to collect data on pre-practicum cognitions, and second set of parallel case scenarios to collect data on post-practicum cognitions. For validation purposes, views of experts were taken. Three departmental instructors at the faculty and three EFL teachers were asked to work through the case scenarios and to give a running commentary on what kind of a challenge they think the researcher is trying to exemplify in each case. In more detail, the experts and the teachers were asked (1) to identify the challenge experienced by teachers in the cases, and (2) to group the cases in terms of the source of challenge experienced. The aim in doing so was to find out whether the type and source of the challenge in each case check out with what is intended to be described by the researcher. The case scenarios took their final forms after some refinements in wording; and one pilot interview was carried out with a different pre-service teacher to see how much time is required and if a problem occurs in the interview process. There is a sample case scenario below: 
Teacher Özge is teaching the $4^{\text {th }}$ unit of the course book. The theme of the unit is 'Dreams' and the grammar point that is aimed to teach is 'When/While Clauses'. Teacher Özge thinks that there are many grammar activities while there are very limited speaking/listening/writing activities in the unit. In this case, Teacher Özge assigns a writing homework to the students and wants them to do it at home.

Two interviews for each of the six pre-service teachers were arranged: first interview prior to the practicum and the second after the practicum. During the interviews, the pre-service teachers were provided with the written versions of case scenarios on separate pieces of paper. What was expected from them was to read the case scenarios one by one and then answer four questions the researchers asked orally following each of the case scenarios. The questions were as follows:

(1) Please choose the source of in-class challenge experienced by the teacher in the case scenario you have just read? Then, please specify the reasons for your choice.
(a)
Learner-related
(b) Resource-related
(c) Educational policy related

(2) What would you do to overcome this challenge if you were in X teacher's shoes?

(3) What is/are the idea(s) behind the way of your thinking?

The first question was asked in order to make sure about their understanding of the type of in-class challenges, i.e. to see if the participants and the researchers have the same point of view in terms of the nature of challenges described in the scenarios. The second question asked for the pre-service teachers' strategies to overcome the challenge. And finally, the basis of their ways of thinking was asked with the third question to have an insight into the influences on their thoughts.

\subsection{Data collection procedures}

Data for this study were collected in two main stages. The first stage involved collection of the baseline data. In this study, base-line data was the initial step in the data collection process and aimed to identify in-class challenges experienced by in-service EFL teachers and these challenges served as the basis of case scenarios which were used in the subsequent stage. A questionnaire with an open-ended item was developed to elicit in-class challenges encountered by EFL teachers. At the second stage of data collection, pre-service EFL teachers were interviewed before the practicum in order to obtain information on their pre-practicum cognitions in relation to overcoming most commonly encountered challenges in EFL teaching. Case scenarios of in-class challenges were used for the interviews. Having completed their practicum, pre-service teachers were interviewed for the second time for obtaining information on their post-practicum cognitions. This time, parallel case scenarios of in-class challenges were used for the interviews. It is important to note here that the language used in the data collection techniques in this study was Turkish since it is thought that individuals can best convey the meaning in their native language. A step-by-step list of the procedure is presented below:

\section{Stage I}

a) Collection of the base-line data from in-service teachers to determine the in-class challenges Stage II

a) Creation of two sets of case scenarios based on the base-line data

b) Collection of pre-practicum cognition data from PTs

c) Collection of post-practicum cognition data from PTs 


\subsection{Data analysis}

In the analyses of each set of data, the framework provided by Miles and Huberman (1994) -that is (a) data reduction, (b) data display, and (c) conclusion drawing/verification - was followed in order to have systematicity in the analyses. In brief, the analytic progression started from what is happening and how, and it proceeded to why it is happening, as suggested in Miles and Huberman (1994). For the analysis of the data in this study, the qualitative data analysis software, 'Nvivo 10' was used.

\subsubsection{Analysis of the base-line data}

The base-line data obtained from English language teachers through 'questionnaire for determining in-class challenges' were analyzed through qualitative content analysis. In the initial coding process of this set of data, descriptive codes were developed out of the teacher statements of in-class challenges. As the next step, a typological analysis was carried out. In this process, major categories that were grounded in the data were determined, and emergent codes of in-class challenges were classified on the basis of the underlying reasons for occurrence. As the last step, enumeration was done and frequencies of the codes were counted.

\subsubsection{Analysis of the cognition data}

The interview data were dealt with in terms of the types of in-class challenges. That is, the unit of analysis for the cognition data was the types of in-class challenges. In the initial coding process, process codes were developed out of the responses of pre-service teachers in explaining their strategies to overcome in-class challenges. Process coding is "particularly appropriate for qualitative studies that search for ongoing action/interaction/emotion taken in response to situations, or problems, often with the purpose of reaching a goal or handling a problem" (Corbin and Strauss, 2008, pp. 96-97). Process codes can be applied to simple observable activity or general conceptual action (Saldana, 2009F), as the cognition data in this study. Next, the number of process codes was reduced as a result of the researcher reflection through the reanalysis of the initial coding work by merging the codes that looked very similar.

\section{Results}

\subsection{In-class challenges experienced at secondary school EFL classes}

This part reports the results of the base-line data regarding the in-class challenges experienced by EFL teachers at public secondary schools. After the analysis, four major categories were developed out of the codes. Table 1 displays classification and types of in-class challenges experienced by EFL teachers working at secondary schools.

Table 1. Classification and types of in-class challenges experienced in public secondary schools ${ }^{\dagger}$

\begin{tabular}{clc}
\hline $\begin{array}{c}\text { Classification of in- } \\
\text { class challenges }\end{array}$ & \multicolumn{1}{c}{ Types of in-class challenges } & $\boldsymbol{f}$ \\
\hline & $\begin{array}{l}\text { Off-task behavior } \\
\text { Variety in English Language } \\
\text { Learner-related } \\
\text { challenges }\end{array}$ & $\begin{array}{l}\text { levels } \\
\text { Difficulty in understanding E- } \\
\text { medium T-talk }\end{array}$ \\
\hline
\end{tabular}

\footnotetext{
$\dagger$ The types of in-class challenges are based on how the informant teachers perceive and categorize them.
} 


\begin{tabular}{|c|c|c|}
\hline \multirow{7}{*}{$\begin{array}{l}\text { Resource-related } \\
\text { challenges }\end{array}$} & Limited study at home & 5 \\
\hline & Total & 32 \\
\hline & Lack of instructional aids & 8 \\
\hline & $\begin{array}{l}\text { Interest value of course book } \\
\text { content }\end{array}$ & 6 \\
\hline & $\begin{array}{l}\text { Complexity of course book } \\
\text { content }\end{array}$ & 6 \\
\hline & $\begin{array}{l}\text { Grammar oriented course book } \\
\text { content }\end{array}$ & 4 \\
\hline & $\begin{array}{l}\text { Vocabulary size in course book } \\
\text { content }\end{array}$ & 3 \\
\hline \multirow{4}{*}{$\begin{array}{l}\text { Educational policy- } \\
\text { related challenges }\end{array}$} & Total & 27 \\
\hline & $\begin{array}{l}\text { Negative backwash effect of the } \\
\text { high school placement exam }\end{array}$ & 7 \\
\hline & Limited weekly course hours & 7 \\
\hline & Total & 14 \\
\hline \multirow[t]{2}{*}{$\begin{array}{l}\text { Physical environment- } \\
\text { related challenges }\end{array}$} & Over-crowded classes & 3 \\
\hline & Total & 3 \\
\hline
\end{tabular}

\subsection{Cognitions of PTs in relation to dealing with in-class challenges}

PTs' cognitions are dealt with in two parts: Cognitions prior to practicum (pre-practicum cognitions) and cognitions after practicum (post-practicum cognitions).

\subsubsection{Cognitions of PTs to deal with learner-related challenges}

PTs considered employing various strategies to deal with learner-related challenges. Table 2 summarizes the strategies PTs came up with in their pre- and post-practicum cognitions according to the types of in-class challenges.

Table 2. PT strategies generated to deal with learner-related challenges in their pre- and post-practicum cognitions

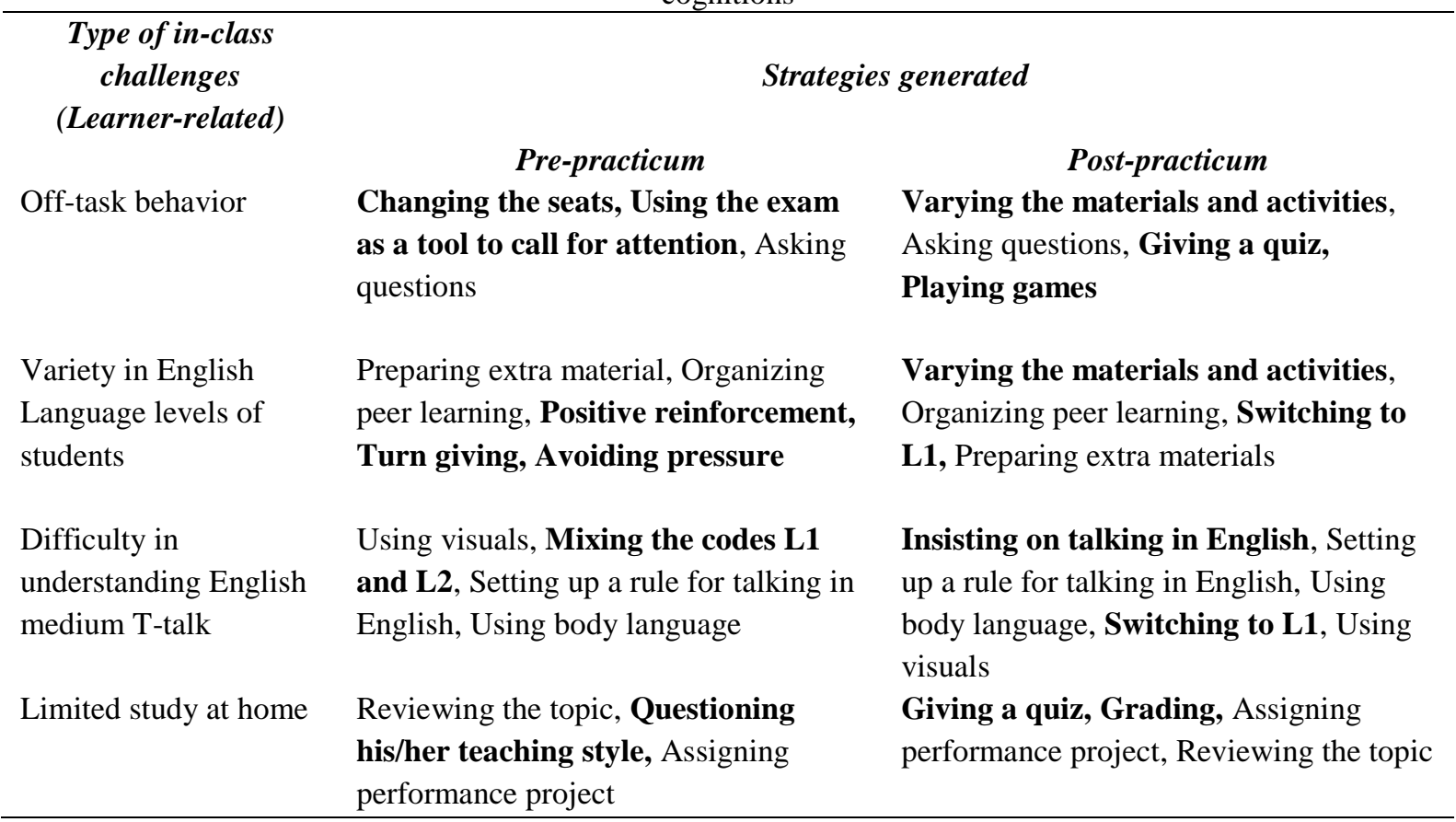


When we examined PTs' cognitions, we observed traces of change in this category. For instance, changing the seats of students in dealing with off-task behavior emerged as a strategy in their prepracticum cognitions while it didn't emerge in their post-practicum cognitions. On the other side, switching to L1 was a strategy of PTs in their post-practicum cognitions but not in pre-practicum cognitions. This change may be due to the reasoning they made about what would or would not work in a real classroom. In Table 2, strategies that show a cognitive change are shown in bold. However, we also observed that some of the strategies remained the same in pre- and post-practicum cognitions. For instance, preparing extra material and organizing peer learning emerged in both pre- and postpracticum cognitions in dealing with the variety in English language levels of students.

\subsubsection{Cognitions of PTs to deal with resource-related challenges}

Several strategies emerged in PTs' cognitions for dealing with challenges due to the resources. Table 3 summarizes the strategies found. PTs generated nine different strategies in total to overcome challenges in this category. Changes in their thoughts was observed in only three strategies, which is less than the previous category of in-class challenges For instance; PTs regarded 'changing the course book' as a strategy before the practicum, but not after the practicum. This change makes sense because it shows that PTs were unaware of the fact that course book cannot be changed by the individual teacher of a class. So, it can be said that they learned this fact and did not regard it as a strategy any more. On the other hand, no change was observed with seven strategies that emerged in both pre- and postpracticum cognitions. Strategies showing a cognitive change are shown in bold font on the table.

Table 3. PT strategies generated to deal with resource-related challenges in their pre- and post-practicum cognitions

Type of in-class

challenges

(Resource- related)

Lack of Instructional Aids

Interest Value of Course Book Content

Complexity of Course

Book Content

Grammar-Oriented

Course Book Content

\section{Strategies generated}

\begin{abstract}
Pre-practicum
Using the Internet to play the listening text \& Bringing her own equipment, Reading out the listening text himself/herself
\end{abstract}

Giving a refreshing break, Modifying the material,

Changing the course book,

Omitting and Adding material,

Using the exam as a threat

Re-ordering the unit, Omitting and Adding material

Omitting and Adding material

\section{Post-practicum}

Using the Internet to play the

listening text \& Bringing her own equipment, Reading out the listening text himself/herself

Omitting and Adding Material, Modifying the material

Re-ordering the unit, Omitting and Adding material Omitting and Adding material

\subsubsection{Cognitions of PTs to deal with educational policy-related challenges}

PTs generated a few strategies to deal with Negative backwash effect of the high school placement exam in their pre- and post-practicum cognitions. Examining their ways of dealing with negative backwash effect, we found out that only one strategy (cooperating with the counselor) changed as it emerged only in pre-practicum cognitions but not in post-practicum cognitions; and two strategies 
(dividing the class hour and explaining the benefits of teacher's way of teaching) remained the same before and after the practicum.

Table 4. PT strategies generated to deal with educational policy-related challenges in their pre- and postpracticum cognitions

\begin{tabular}{|c|c|}
\hline $\begin{array}{l}\text { Type of in-class } \\
\text { challenges }\end{array}$ & Strategies generated \\
\hline (Edu. Policy related) & Post-practicum \\
\hline $\begin{array}{l}\text { Negative backwash } \\
\text { effect of the high school } \\
\text { placement exam }\end{array}$ & $\begin{array}{l}\text { Dividing the class hour, Explaining the benefits of teacher's } \\
\text { Cooperating with the counselor, way of teaching, Dividing the class } \\
\text { Explaining the benefits of hour } \\
\text { teacher's way of teaching }\end{array}$ \\
\hline
\end{tabular}

When the rate of change between PTs' pre- and post-practicum cognitions according to the categories of in-class challenges is compared, it can be said that PTs' ways of dealing with resource-related challenges and educational policy-related challenges showed very limited change in pre- and postpracticum cognitions compared to their ways of dealing with learner-related challenges. The rate of change was calculated by getting a percentage of the strategies that showed a cognitive change. Figure 1 displays the rates of change in percentages.

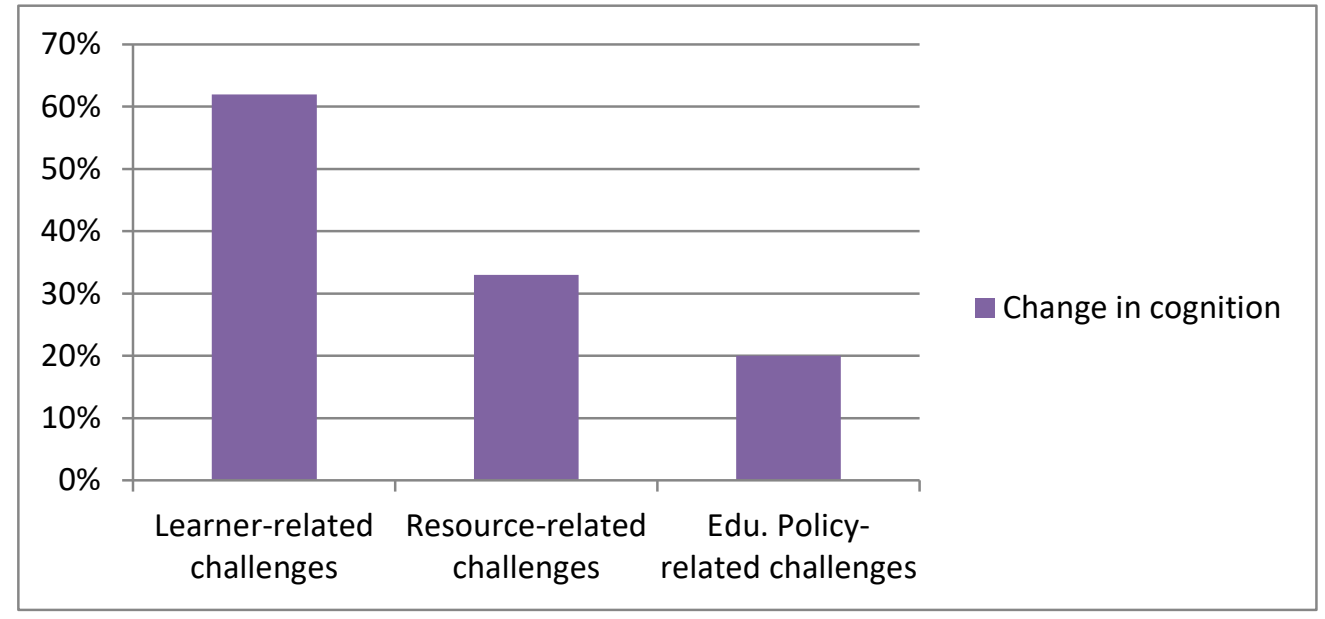

Figure 1. Comparison of change in percentage between PTs' pre- and post-practicum cognitions according to the categories of in-class challenges

The reason why PTs showed greater cognitive change after the practicum in dealing with learnerrelated challenges (62\%) is thought to depend on the very human factor this category involves. Challenges due to learners embody various aspects to consider and every individual teacher in different contexts has different points of view when finding ways to deal with them. Those aspects may have psychological, sociological, educational, etc. backgrounds that affect both learners and teachers in a decision-making process. This variety is thought to account for greater change in PTs' overcoming strategies in their cognitions in learner-related challenges compared to the other two. As for the challenges due to the resources, limited change (33\%) between strategies PTs came up with in their cognitions is due to more systematic and formulaic ways those types of challenges seem to evoke for solution. Simply, there are many reference books that present ways like formulas to deal with such challenges on the market and PTs most probably contact with those publications, at least in the courses 
of the teacher education program. On the other hand, educational policies do not provide much autonomy in teachers, and so it is normal to go through limited cognitive change (20\%) since there are few actions to take for overcoming challenges stemming from them.

\subsection{Influences that shape PTs' cognitions in relation to dealing with in-class challenges}

\subsubsection{Influences that shape PTs' pre-practicum cognitions}

PTs' thought processes revealed that their pre-practicum cognitions are shaped by their own learning experiences and courses they take in teacher education program. PTs' own learning experiences more intensely affect cognitions than courses they take in teacher education program. PT's own learning experiences has a $58 \%$ rate of reference while courses in teacher education program has $42 \%$ rate of reference in PTs' thought processes to deal with in-class challenges.

PTs relate the overcoming strategies to their own learning experiences for nearly all types of in-class challenges. They refer to them as in the following responses:

What caused me think in this way was that my previous teachers did the same thing; they changed our seats when we chatted in the class; they made us sit with someone we didn't like. We couldn't talk with somebody we didn't like and so listened to the teacher, or at least sat silently. (PT A, for off-task behavior)

The reason why I think in this way is that I myself didn't study without a requirement. But, when I had a forcing teacher, I studied since I was afraid of getting low marks. So, I think that forcing students really work. For example, when I was a student in the preparatory class, we took quiz every week and so I had to get prepared for it every week and it contributed a lot in terms of recalling the topics. Additionally, by this way you can really learn without memorization. You can recall everything. (PT N, for limited study at home)

As obvious from the above extracts, a majority of the PTs benefit from their own learning histories and their own teachers' practices. They revealed that they would behave in parallel with their teachers to cope with challenges. However, STs, in some situations, criticize their prior teachers' practices and approaches. As in the following response, they think they would behave in a different way from them.

Teachers ought to make self-criticism but it is not the case generally. When I think about my previous teachers, I notice this was not the case as well. They behave as if the problem is with the students all the time. But, self-criticism is an important skill in teaching. If things are not going on properly, it is also necessary that we make self-criticism. (PT C, for limited study at home)

Besides their own learning experiences, PTs' pre-practicum cognitions are based upon the courses they take in teacher education program. They referred to what they have learned in the courses to deal with in-class challenges caused by especially grammar-oriented course book content and variety in language levels of students. The following extracts are examples:

What causes me think in this way is the 'methodology' and 'approaches and methods in ELT' courses here, at my university. We have learned in the theory of those courses that language can't be taught by only presenting grammatical information. It is necessary to teach a language by developing all the skills. (PT A, for grammar-oriented course book content)

There is no sense in teaching a language without developing speaking and listening skills in it. The education I have taken taught me this. Communicating is the main aim of 
language learning. Knowing about the grammar of a language is meaningless if it is not used in communicating. (PT C, for grammar-oriented course book content)

PTs sometimes refer to a specific course, for instance 'approaches and methods in foreign language teaching' course, and sometimes to the whole program for the strategies they generate. They think they would behave in parallel with what they have learned.

\subsubsection{Influences that shape PTs' post-practicum cognitions}

Influences that shape the ways PTs deal with in-class challenges (after they completed the practicum) include courses in teacher education program, practicum experiences, and their own learning experiences. Practicum experiences was found to affect the PT cognitions the most intensely, with a $40 \%$ rate. Here, practicum experiences include not only PTs' practice teaching but also all kind of tasks they engaged like classroom observations. Then, PTs referred to courses in teacher education program for suggesting ways to deal with challenges, with a $35 \%$ rate. PTs fell back upon their own learning experiences with a $25 \%$ rate to come up with possible solutions for the challenges.

Practicum experiences, which are first actual teaching practices of the PTs in this study, have become a source of reference for them in finding out ways to overcome in-class challenges. It is seen that they reflect on the incidents and student attitudes that took place during their practice teaching sessions. Further, they benefit from them in generating strategies for dealing with different in-class challenges. The following extracts set examples for the case.

Students who have been accustomed to the use of Turkish in English classes may have difficulty, so it is necessary to support teaching through visuals and bodily movements. They really don't understand when you teach through plain talk. But, they can understand better when you support your talking. I experienced this when I taught at the practicum school. (PT A, Difficulty in understanding E-medium T-Talk)

Students would get rid of their negative attitudes if we persuade them that they could understand classroom talk in English. They get accustomed to it in time; for example in the class I taught at the host school, their teachers thought that they didn't understand and always talked in Turkish. But, I talked in English in all three classes I taught. First they complained a lot, they said that they didn't understand, but this faded gradually. They got accustomed to my style. Most of them understood. (PT N, for Difficulty in understanding E-medium T-Talk)

Furthermore, observing classes gave ideas to PTs. For instance, PT N criticized some teaching practices of the mentor teacher and those views of her shaped the way she thought over dealing with challenges after the practicum. The following extract exemplifies the case.

It is wrong to teach the topics one after another in such a short academic period. The topics should be presented through sufficient and varied activities for permanent learning. But, this is not the case in schools; teachers may just present a topic for the sake of having taught it and then move on to the next. Then, students try to adapt themselves to the newly presented topic without having learnt the previous one properly. There were cases of this kind, at least, at the school I went for practicum. (PT N, for Complexity of course book content)

Additionally, PTs drew out some of the incidents in the classroom and those observations formed a know-how that influence their ways of overcoming challenges after the practicum. The following extracts explain the rationale behind PTs' overcoming strategies. 
Things that are not revised are forgotten. Revision that is made through enjoyable ways is more beneficial. I have observed that students especially of this age like learning through games very much. For this reason, I would deal with this problem by the help of games. (PT B, for Limited study at home)

As I said before, we have to be tactful. We will already experience a lot of unexpected challenges with students. In practicum we have observed how changeable the classroom atmosphere is. One classroom isn't the same as another one. Course books can be more fruitful if we make up their deficiencies beforehand and we can enhance the use of them. (PT C, for Grammar-oriented course book content)

PTs establish a relationship between the strategies they develop and the courses they have taken in teacher education program. Some of them referred to the key facts of education and the points emphasized during the program to support their opinions, as in the following extract.

Each student is unique and learns in different ways. This has been one of the most important things that are emphasized throughout our four-year education. (PT G, for Variety in English Language levels of students)

Moreover, PTs pointed to some specific courses they have taken in the teacher education program. The courses they referred to were materials development and evaluation in language teaching, teaching language skills, and educational psychology when thinking about how to deal with challenges especially related to instructional resources. They believe that teachers should make use of theory and information in those fields to find a way out of the challenges encountered in the class.

There is no such rule that the books are correct or they have a correct approach all the time. One of my responsibilities as a teacher is to evaluate this and make necessary arrangements. The one who knows a classroom best is the teacher; and it should be under a teacher's authority to use a book or not. We should benefit from the courses on 'material development and evaluation' we have taken at the university and behave in the light of them. (PT S, for Complexity of course book content)

Students don't want to do boring things that they don't like. And to overcome this, it is necessary to know about some strategies and use them. For this, it is necessary to benefit from branches of educational sciences like educational psychology. (PT B, for Interest value of course book content)

Learning experiences is still another powerful influence on STs' post-practicum thoughts. It can be clearly inferred from their responses that STs fall back on their prior experiences as a student and this obviously helps them empathize with students. The following response shows that they put themselves in students' place in dealing with challenges.

We have been students and experienced the same situation many times. Trying to write something meaningless makes no sense. First, students should be directed to writing through enjoyable activities for increasing motivation and a meaningful context is required. (PT C, for Interest value of course book content) 


\section{Discussion}

\subsection{Discussion of the results regarding PTs' cognitions}

In the study, six PTs' cognitions in dealing with in-class challenges were examined both on the prepracticum and post-practicum dimensions. As a result, PTs generated a multitude of strategies to deal with different types of in-class challenges, and a great deal of change between pre- and post-practicum cognitions was observed for learner-related challenges while there is limited change between pre- and post-practicum cognitions in dealing with resource-related and educational policy- related challenges.

Therefore, it can be concluded that this study produced "mixed findings" (term by Borg, 2011). Change in PTs' thoughts showed variety according to the category of in-class challenges. That is parallel to the findings of Han et.al., (2017) who found that change in beliefs on intention to use technology in teaching showed difference according to the characteristics of PTs. Similarly, Polat (2010) reported changing/unchanging and more favorable/less favorable beliefs of PTs before and after a pedagogical treatment. Liu and Fisher (2006) was another study that reported varying results in change of beliefs on self-conception. Overall, what is concluded in this study add to the results reported by the existing literature.

\subsection{Discussion of the results regarding influences that shape PTs' cognitions}

The results of the present study indicate that PTs' own learning experiences and courses in teacher education program influenced PTs' cognitions before the practicum,. Having completed the practicum, it was not surprising to find out the influence of practicum experiences on PTs' cognitions, even as the strongest influence.

The results of this study regarding influences on cognitions find support from the existing literature on teacher thinking. The results of this study are parallel to what have been concluded in the existing literature that foreign language teacher education, teachers' prior language learning experience, and their classroom experience are affecting teachers' thought processes (Zheng, 2009; Farrel, 2008). On the other hand, some of the researchers evaluated the extent to which those influences impact on their cognitions. Urmston (2003) found out the relatively stronger influence of time passed in classrooms for the practicum compared to PTs' own language learning experiences and training taken in teacher education program in his longitudinal study, which is in line with the results of this study as practicum experiences being the strongest influence on post-practicum cognitions. Numrich (1996) reported that the effect of learning an L2 is often carried over to the teaching of an L2, either by "replicating" or "rejecting" techniques used by previous teachers. This finding of Numrich's (1996) research is fully in line with the present study in that PTs in this study praised and replicated some of their previous teachers' approaches to language teaching, while they criticized and rejected some of them in their cognitions in dealing with in-class challenges.

There are varying conclusions about the impact of teacher education programs on teacher thinking and the extent to which the programs change teachers' beliefs. Richards and Pennington's (1998) study revealed that the teachers mostly ignored and abandoned the principles they had been taught in their teacher preparation program, and they concluded that the teacher preparation program could not make changes in the teachers' schema against cultural classroom tradition they had experienced as students. In another study, Pennington and Urmston (1998) claimed that graduating English language teachers were not greatly affected by the coursework in the teacher preparation program but rather by the teaching culture of the local education context, in which they involved as students for many years and as PTs during the program. Nevertheless, in this study teacher education program was found to be the strongest 
influence on PTs' pre-practicum cognitions and the second strongest influence on PTs' post-practicum cognitions.

\section{Conclusions}

This qualitative study attempted to investigate cognitions of pre-service English language teachers (PTs) in dealing with most-commonly experienced in-class challenges, changes in their cognitions, and the influences that shape their ways of thinking. With this aim, three research questions were addressed and the study revealed the following major results:

1. PTs generated various strategies to deal with in-class challenges in their pre- and postpracticum cognitions.

2. Greater change was observed in PT cognitions to deal with learner-related challenges yet there was limited cognitive change in dealing with resource-related and educational policyrelated challenges.

3. Courses in teacher education program, their own learning experiences, and practicum experiences emerged as influences that shape their cognitions in dealing with those challenges.

There are a number of implications that can be drawn in this study for English language teacher educators, foreign language teacher preparation programs, and the practice teaching component of those programs. Firstly, types and classifications of in-class challenges determined in this study can be used for raising the awareness of PTs, especially practicum seminars. Further, PTs may be trained in terms of dealing with those challenges and theory-informed solutions may be suggested. Case-based methods can be adopted in training PTs and scenarios of in-class challenges may be used for this aim. The use of real in-class challenges explained in scenarios may provide opportunities for PTs to think over them and produce ideas for solutions which they may benefit in their induction year. This may also be an effective way for developing their instructional skills. Further, cases can be analyzed by integrating theories in discussions, and by this way PTs' knowledge of theory can be extended, tested, and consolidated (Sykes and Bird, 1992).

Moreover, the study contributes to the literature on the influences that shape cognitions of PTs. The practicum can be regarded as a key to cognitive change and so as an opportunity to guide PTs. Teacher education programs can create opportunities for PTs to be conscious of their own thought processes, because what shapes their instructional practices is their thinking. In some courses such as the practicum, teacher educators can provide opportunities to make PTs' thought processes explicit and work on them. Only by this way can they reconstruct their cognitions.

\section{Acknowledgements}

This study was produced from the Ph.D. dissertation of the first author.

\section{References}

Bailey, K. M., Berghthold, B., Braunstein B., Fleichman N. J.,. Holbrook, M., Tuman, P J., Waissbluth X., \& Zambo, L.J. (1996). The language learners' autobiography: Examining the "apprenticeship of observation". In D. Freeman and J. C. Richards (Eds.), Teacher learning in language teaching. (pp. 11-29). Cambridge University Press. 
Bartels, N. (2009). Knowledge about language. In A. Burns and J. C. Richards (Eds.) The Cambridge guide to second language teacher education. (pp. 125-134). Cambridge University Press.

Basturkmen, H. (2012). Review of research into the correspondence between language teachers' stated beliefs and practices. System: An International Journal of Educational Technology and Applied Linguistics. 40(2). 282-295.

Borg, S. (2003). Teacher cognition in language teaching: A review of research on what language teachers think, know, believe, and do. Language Teaching. 36, 81-109.

Borg, M., (2005). A case study of development in pedagogic thinking of a pre-service teacher. TESLEJ, 9, 1-30.

Borg, S. (2005). Experience, knowledge about language, and classroom experience in teaching grammar. In N. Bartels (Ed.). Applied linguistics and language teacher education. (pp. 325-340). New York: Springer.

Borg, S. (2006). Teacher cognition and language education: Research and practice. London: Continuum.

Borg, S. (2011). The impact of in-service education on language teachers'beliefs. System, 39, 370-380.

Borg, S. (2012). Current approaches to language teacher cognition research: A methodological analysis. In R. Bernard and A. Burns (eds.). Researching language teacher cognition and practice: International case studies. (pp. 11-29). Multilingual Matters.

Breen, M. P., Hird, B., Milton, M., Oliver R. \& Thwaite, A. (2001). Making sense of language teaching: teachers' principles and classroom practices. Applied Linguistics, 22 (4), 470-501.

Burns, A. (1996). Starting all over again: From teaching adults to teaching beginners. In D. Freeman and J. C. Richards (Eds.). Teacher learning in language teaching. (pp. 154-177. Cambridge: Cambridge University Press.

Cabaroglu, N. \& Roberts, J. (2000). Development in student teachers' pre-existing beliefs during a 1year old PGCE programme. System, 28, 387-402.

Clandinin, D.J. (1985). Personal practical knowledge: A study of teachers' classroom images. Curriculum Inquiry. 15(4). 361-385.

Clark, C. M. And P. L. Peterson (1984). Teachers' thought processes. Occational Paper No 72. Downloaded from: ERIC, Number: ED251449

Corbin, J. and Strauss, A. (2008) Basics of qualitative research: Techniques and procedures for developing grounded theory (3rd ed.). Thousand Oaks, CA: Sage.

Dörnyei, Z. (2007). Research methods in applied linguistics: Quantitative, qualitative, and mixed methodologies. Oxford: Oxford University Press.

Farrel, T. S. C. (2008). Learning to teach language in the first year: A Singapore case study. In Farrel T. (Ed.) Novice language teachers: Insights and perspectives for the first year (pp. 43-56S). C. Equinox.

Flores, B. B. (2001). Bilingual education teachers' beliefs and their relation to self-reported practices. Bilingual Research Journal. 25, 251-275.

Gholami, K. and J. Husu (2010). How do teachers reason about their practice? Representing the epistemic nature of teachers' practical knowledge. Teaching and Teacher Education, 26, 15201529 . 
Golombek, P. R. (1998). A study of language teachers' personal practical knowledge. TESOL Quarterly. 32, 447-464.

Golombek, P. R. (2009). Personal practical knowledge in language teacher education. In A. Burns \& J. C. Richards (Eds.), The Cambridge guide to second language teacher education. (pp. 155-162). Cambridge University Press.

Gomez, M.L. (1990). Reflections on research for teaching: Collaborative inquiry with a novice teacher. Journal of Education for Teaching. 16(19). 45-56.

Grisham, D., L.. (2000). Connecting theoretical conceptions of reading to practice: A longitudinal study of elementary school teachers. Reading Psychology. 21. 145-170.

Han, I., Shin, W. S. \& Ko, Y. (2017). The effect of student teaching experience and teacher beliefs on pre-service teachers' self-efficacy and intention to use technology in teaching. Teachers and Teaching, 23(7), 829-842.

Liu, Y. \& Fisher, L. (2006). The development patterns of modern foreign language student teachers' conceptions of self and their explanations about change: Three cases. Teacher Development, 10 , 343-360.

Lortie, D., C. (1975). Schoolteacher: A sociological study. The University of Chicago Press.

Meijer, P.C., Verloop, N., \& Beijaard D. (1999). Exploring language teachers' practical knowledge about teaching reading comprehension. Teaching and Teacher Education. 15, 59-84.

Miles, M. B. \& Huberman, A. M. (1994). Qualitative data analysis. Sage Publications.

Numrich, C. (1996). On becoming a language teacher: Insights from diary studies. TESOL Quarterly. 30(1). 131-153.

Pajares, M. F. (1992). Teachers' beliefs and educational research: Cleaning up a messy construct. Review of Educational Research, 62. 307-332.

Pennington, M. C. And A. Urmston. (1998). The teaching orientation of graduating students on a BATESL course in Hong Kong: A comparison with first year students. Hong Kong Journal of Applied Linguistics. 3(2). 17-45.

Phipps, S., (2007). What difference does DELTA make? Cambridge ESOL: Research Notes, 29, $12-$ 16.

Polat, N. (2010). Pedagogical treatment and change in preservice teacher beliefs: An experimental study. International Journal of Educational Research. 49, 195-209.

Richards, J. C., Ho, B., \& Giblin, K. (1996). Learning how to teach in the RSA cert. In D. Freeman \& J. C. Richards (Eds.), Teacher learning in language teaching (pp. 242-259). Cambridge: CUP.

Richards, J. C. (1996). Teachers' maxims in language teaching. TESOL Quarterly. 30, 281-296.

Richards, J. C. \& Pennington, M. (1998). The first year of teaching. In J.C. Richards (ed.). Beyond Training. (pp. 173-190). Cambridge University Press.

Saldana, J. (2009). The coding manual for qualitative researchers. SAGE Publications.

Santoro, N. and A. Allard. (2008). Scenarios as springboards for reflection on practice: Stimulating discussion. Reflective Practice, 9(2), 167-176.

Sykes, G. and T. Bird. (1992). Teacher education and the case idea. Review of Research in Education. 18, 457-519. 
Tsui, A. B. M. (2011). Teacher education and teacher development. In E. Hinkel (ed). Handbook of research in second language teaching and learning (Vol. II. pp. 21-39). New York: Routledge.

Tüzel, A. E. B. and S. Akcan. (2009). Raising the language awareness of pre-service English teachers in an EFL context. European Journal of Teacher Education. 32(3). 271-287.

Urmston, A. (2003). Learning to teach English in Hong Kong: The opinions of teachers in training. Language and Education. 17(2). 112-137.

Williams, M. and Burden, R. L. (1997). Psychology for language teachers: A social constructivist approach. Cambridge: Cambridge University Press.

Warford, M.,K. and J. Reeves. (2003). Falling into it: Novice TESOL teacher thinking. Teachers and Teaching: Theory and Practice. 9(1). 47-65.

Woods, D. \& Cakır, H. (2011). Two dimensions of teacher knowledge: The case of communicative language teaching. System, 39(3), 381-390.

Woods, D. (1996). Teacher cognition in language teaching: Beliefs, decision-making and classroom practice. New York: Cambridge University Press.

Wright, T. (2005). Classroom management in language education. Palgrave Macmillan UK.

Zheng, H. (2009). A review of research on EFL pre-service teachers' beliefs and practices. Journal of Cambridge Studies. 4(1), 73-81.

\section{Sınıf içi zorluklarla baş etme: Hizmet öncesi öğretmen bilişi ve şekillendiren unsurlar}

\section{$\ddot{O} \mathbf{z}$}

Bu çalışma hizmet öncesi İngilizce öğretmenlerinin yabancı dil öğretiminde sık karşılaşılan sınıf içi zorluklarla baş etmelerine ilişkin bilişleri ve bunları şekillendiren unsurları incelemektedir. Nitel araştırma desenini benimseyen bu çalışmada, hizmet öncesi İngilizce öğretmenlerinin bilişlerinin araştırılması amacıyla bir durum çalışması yürütülmüştür. Çalışmanın veri grubu iki ana aşamada toplanmıştır. İlk aşamada saha çalışması yapılmış ve hizmet içi İngilizce öğretmenlerinden açık uçlu bir anket aracılığıyla sık karşılaşılan sınıf içi zorlukları belirlemek amacıyla veri toplanmıştır. İkinci aşamada ise, hizmet öncesi İngilizce öğretmenleriyle staj öncesi ve staj sonrasında senaryo bazlı görüşmeler yapılmıştır. Çalışmanın sonucunda (1) hizmet öncesi İngilizce öğretmenlerinin staj öncesi ve staj sonrası bilişlerinde çeşitli stratejiler ürettikleri, (2) bilişlerinde staj sürecinden kaynaklanan farklılaşmalar olduğu, (3) öğretmen yetiştirme programında aldıkları dersler, kendi öğrenme deneyimleri ve staj sürecindeki deneyimlerinin bilişlerini şekillendiren unsurlar olarak ortaya çıktı̆̆ı açığa vurulmuştur. 


\section{AUTHOR BIODATA}

Şeyda Selen Çimen holds a Ph.D. at Middle East Technical University and works at Muğla Sitkı Koçman University, Department of Foreign Languages Education. Her research interests include language teacher education, teacher cognition and practices, and classroom research.

Ayşegül Daloğlu is a professor at Middle East Technical University, Faculty of Education, Department of foreign Language Education. Her areas of professional interest include curriculum design and evaluation, ELT methodology, testing and assessment, teacher education and professional development, classroom research, and technology use in language education. 